\title{
How to improve the quality of post practical training of vocational schools
}

\author{
Niu Yong-chao \\ Henan Forestry Vocational College 471002 Luo Yang
}

\begin{abstract}
Post practical training vocational college students is an important teaching practical skills. This article on how to vocational schools to ensure that students post practical training quality problems, thinking and understanding to do the work of students from post practical training, clearly define the powers and responsibilities of the post practical training course in schools, businesses and students tripartite properly handle post practical training course the main problems arise aspects were discussed.
\end{abstract}

Keywords-Vocational schools, Post practical training, Teaching Quality

Post practical training vocational college students is an important teaching practical skills. It enables students to fully perform all the duties of internship positions to achieve significant distance employment after graduation. Currently, the main use of vocational schools " $2+1$ " or "2.5 +0.5" education model, where "1" or "0.5" are embodied in post practical training of students before graduation. Strengthen management, quality assurance post practical training, the student will not be the last school year (or semester) "sheep" or become cheap labor, is a work of vocational schools must do a good job.

In 2010, Henan Forestry Vocational College opened a marketing professional, in September 2012 was the profession of teaching reform of college as a professional. In the teaching reform, to strengthen the cultivation of students' practical skills, apart from the students to the last semester post practical training, but also with the Luoyang tourism economic development in China during the Luoyang Peony Festival, Luoyang City, the famous tourism enterprises cooperation, to enable students to participate in promotional work Luoyang specialty restaurant food, peony cultural tourism. After post practical training, students' practical ability has been greatly improved, we have accumulated a certain amount of management experience, is combined with actual work, elaborate on our views。

Post practical training to ensure quality, we must strengthen the management of the following three aspects:

\section{STUDENT'S THINKING AND UNDERSTANDING OF WORK TO DO}

Currently, many students have part-time during the school learning experience. This experience will help improve their ability to work, rich social experience, it tends to make their arrangements for the post practical training schools produce some erroneous thinking and understanding. Mainly for the following.
First. Since it is to participate in the production practice, where all the same, do not have to arrange to go to school internships. After generating this understanding, students will try to disobey the school's arrangements for a variety of reasons as an excuse to escape the post practical training school arrangements.

For this thinking and understanding, to enable students to understand the different schools post practical training and the use of spare time to do part-time work. Internships are a teaching school, mainly through school-enterprise joint guidance, strengthen students' professional skills in practical work, full-time internship is a short-term activity. Therefore, students must submit to the school's teaching arrangements cannot be adjusted without permission.

Second. Fear internships tube too strict, himself insisted on not down. Students produce this idea, mainly because there is no smooth realization of the role reversal. After all, the school's management and business is different, with respect to business management, school management more humane sanctions also lighter. During the students learn in school if not strict with themselves, the internship process will be due to fear of being expelled from the pressure to produce ideas for strict management of enterprises.

For this idea, the school students to do well in advance psychological counseling for students to recognize that the pursuit of economic efficiency of enterprises is a unit of employees subject to management is to achieve the economic benefits of protection. Although students are internships, but to participate in the production business practice, it is necessary to switch roles, can no longer see themselves as a student, but should see themselves as fulltime employees of enterprises. Others can adapt corporate governance requirements, himself as a highly professional education students also must have the confidence to adapt to, and even better than others do.

Third. Consider themselves suited internship positions, so I want to back down. Some students an internship positions to find the work content is not himself imagine, they consider themselves suited to the job, resulting in resentment, asked for a job or internship exchange. There was a student internship units engaged in telemarketing job, had a consistent work content and its professional learning, but the face of daily customers need to call two hundred tasks, feel they simply can not be completed, simply do not do it on the grounds that did not fit. The instructor to let him stick two days to see the results two days down in tears all day, but also affected other internship students. 
For this thinking and understanding instructor to convince students to stabilize mood, give yourself a time to adapt and work hard. After this period, if the student is still difficult to accept this job, we must consider its swap jobs immediately or units, so as not to affect the mood of the other students. But let him know that if they do not change their attitude, to a new job would have a similar problem.

Fourth. Consider internships to the wages are too low, as their part-time cost-effective. Companies to accept student internships, because time is short, the student may not remain in the company after the end of the internship work, but companies also have to shoulder the responsibility of students, which is bound to increase human resource management costs. Human shortages unless otherwise short-term internships for students enthusiasm is not high. School students to create internship opportunities in order to allow companies to accept students in internships, but to accept the relatively low remuneration. But it will cause dissatisfaction of students, part-time cost-effective to do it yourself feel better.

In such thinking and understanding, the instructor to make students understand the essence of internships are internships, the main purpose is to use corporate resources, improve their professional skills and overall quality, rather than to make money. Students cannot take internships equivalent to employment, working conditions and work too much to consider treatment.

Fifth. The internship is a personal thing, nothing to do with the quality of the work of the school. Students have this knowledge, often not constrained in the internship process yourself, do not comply with the provisions of the unit, leave, late, leave early or even more reason not to go to work the phenomenon, because it is not subject to management is ultimately internships early dismissal.

Schools should allow students to understand that practice is teaching arrangements, must be disciplined as internships at the same school. Practice both exercise their own, it is propaganda school. If performed well, not only can fight employment opportunities, but also for the school won a reputation; If the performance is not good, he cannot harvest, but also make internships for students or school evaluation is not good. Instructor to teach students ethical and not simply seen as a personal thing internships, to have a collective sense of honor, in the face of the customer, take the initiative to maintain the image of internship units.

\section{A CLEAR DIVISION OF POWERS AND RESPONSIBILITIES INTERNSHIP SCHOOLS, BUSINESSES AND STUDENTS IN THE PROCESS}

Post practical training course in school, only between companies and students clear their powers and duties, in order to exercise their rights in the internship process, fulfill their responsibilities and obligations. Therefore, arrange internships to students before school, internships, and students themselves or their parents must sign a written agreement to define the rights, responsibilities and obligations of the three parties forming certain binding, thus ensuring the quality of training, but also for in the event of a dispute during the internship, especially the larger things such as accidental injury when providing basis. Among them, the school and internships to students internships signed an agreement with the student or parent to practice the management of students signed an agreement to guide students with internships signed a labor agreement.

First. Schools and businesses together to establish a sound practice management, security management, process management, appraised incentives, performance evaluation and other systems. Achieve excellence in management, refine, quantify job responsibilities and goals, comprehensive tracking and management for students. Each unit must have an internship attendant training instructor, student internships circumstances responsible for checking every day, good inspection records. Also, responsible for student counseling and emotional counseling, students solve specific problems encountered in practice, good communication between schools and businesses.

Second. Companies should be equipped with a dedicated management staff and instructors, students do a good job internship performance appraisal. Managers to objectively and fairly, treat work seriously, life and approachable. Instructor to technical ability, strong communication skills, work experience, be able to grasp the psychological characteristics of students, guide students to take the trouble to do.

Third. Students have to obey the regulations of enterprises, carefully written training log, summed internship experience. To humbly ask the instructor to the enterprise, and timely communication with the school counselor and teacher led a day.

\section{PROPERLY HANDLE THE MAJOR PROBLEMS THAT OCCUR DURING INTERNSHIP}

Students during the internship, due to changes in environment and lifestyle content, it is prone to various aspects of, if not properly handled, will be intensified, affecting the practical effect. Therefore, to correctly handle a good internship process problems, strengthen communication between schools, businesses, students.

Students leaving midway problem. In the course of the internship, the students leave is a common thing, cause students to leave for personal reasons there are reasons both practical units. Personal reasons, such as lack of patience and hard-working spirit, physical health problems, absenteeism, sabotage, violations of corporate discipline, employment gap between expectations and actual work to generate greater psychological gap, poor adaptability, not satisfied with the work environment, etc.; 
reasons of internships such as wage arrears students, free to extend working hours, labor-intensive, random changes in internship or job content.

Should do the job from the following three aspects to this problem:

First, internship before communication between schools and students. Schools must first inspect the internship, the student internship job content, working conditions and requirements to be aware of. Strengthen discipline former student internships and professional qualities, sense of responsibility, integrity quality education, education students dedication, hard-working, thrift, and inform students of the importance of internships and school-related approach on unauthorized leave, in order to avoid free to leave.

Second, the process of communication practice between schools and businesses. In addition to requiring students to practice responsibility and obligation in the agreement, schools and businesses need to reach a consensus. Enterprise performance for students in the internship process violations should be promptly informed of school teachers led by its ideological education teacher or a warning, such as education is still correct, companies under the premise can inform the school dismissed students. In the case of business schools is not unaware of the unauthorized dismissal of students.

Third, communication between businesses and student internship process. Business management student in accordance with staff management approach, focusing dedication, ethics and corporate regulations, safety in production, technical specifications, production procedures, quality standards, service awareness education. Student internships in business management as to have objections to the internship reflects management or instructor. If companies ignore it, the students can be reflected by the school attendant instructor, to solve the problems and eliminate hidden dangers to leave.

Students found responsible for the accident safety issues. Security incidents in the labor process, the employer and the employee cannot be avoided. Accidents occurring in the student internship process cannot be recognized as work-related accidents and serving as laborers, for processing in accordance with the relevant provisions of labor law and labor insurance. In China's current laws and regulations do not clearly identify responsibilities, which often causes disputes.

Conclusion For this problem, in the agreement occurred during the internship students should make clear that workers' compensation, the use of work-related injury insurance mechanism, strengthen the maintenance of stakeholders and in accordance with relevant laws and regulations, and properly handle student injury problems.

Student internships working conditions and remuneration issues. Some companies put student interns as cheap labor and less to give or not to pay, job placement arbitrary. Some companies even believe that internships are already able to accept students to the school, to help the students, but also to talk about compensation ? Therefore, during student internships, internships prone to random changes in status or job content, free to extend working hours, wage arrears problem students .

When dealing with such issues should be dealt with in accordance with the general national or local laws, rules and regulations ; negotiation fails, you can complain to the local labor department . "Decision of the State Council on vigorously develop vocational education ," pointed out : " the establishment of enterprise receiving vocational college students internship system , enterprises should jointly organize a good student and school -related theories of teaching and professional work skills training, good student internships in labor protection, safety , etc., as a trainee students pay reasonable compensation ." Thus, resulting in a de facto relationship between labor long internship students and internships, interests on both sides are subject to " the protection of labor law ".

" Henan Province on strengthening vocational college students practice management notice" for the treatment of vocational school students internships, internships conditions and internship positions were rules and restrictions, regulations daily working hours shall not exceed eight hours, shall arrange for students to work overtime ; ban the student engaged in venture arrangements do not meet the characteristics or practice inconsistent with the practice of labor and production .

In short, students do ideological work, a clear division of rights and responsibilities of schools, businesses, and between students and properly handle the major problems that appear in practice, will help students in vocational schools do practice management, quality assurance practice .

\section{REFERENCES}

[1] LIU Xue-wen. Problems in Internship Program for Higher Vocational College Students and Countermeasures [J]. Journal of Wuhan Institute of Technology. 2008 (2):58-61.

[2] WAN Ping. Strategies of Improving Teaching Quality in Post Practice of Higher Vocational and Technical Education [J]. Journal of Luoyang Technology College. 2006,16(12):59-62

[3] Su Yong. Taking Post for Field Work and Replacement Training-Constructing the All-in-one New Mode of Normal Students 'Educational Field Work and Rural Secondary School Teacher Training [J].Educational Research. 2009(8): 104-107.

[4] WANG Jin-gang. Study and Practice of Effective Teaching Evaluation of Post Practice in Higher Vocational Education[J].Vocational and Technical Education.2010(11):57-60.

[5] Shi Wei-ping, Tang Zhi-bin. Enhancing the Attraction of Vocational Education in China: Problems and Countermeasures[J]. Research in Educational Development. 2009,13:20-24. 